\title{
Palaeomagnetic correlation of the Upper Triassic of Somerset, England, with continental Europe and eastern North America
}

\author{
J. C. BRIDEN ${ }^{1,2} \&$ B. A. DANIELS ${ }^{2}$ \\ ${ }^{1}$ Environmental Change Unit, University of Oxford, 5 South Parks Road, Oxford OX1 3UB, UK \\ (e-mail: jim.briden@ecu.ox.ac.uk) \\ ${ }^{2}$ Department of Earth Sciences, University of Oxford, Parks Road, Oxford OX1 3PR, UK
}

\begin{abstract}
Three Normal and three Reversed palaeomagnetic polarity zones were identified in the exposed $67 \mathrm{~m}$ section of Mercia Mudstone at St Audrie's Bay, Somerset, which has been regarded as being of Norian age on limited biostratigraphic evidence. The polarity sequence is correlated with magnetozones E15 to E17 in the Newark Basin, New Jersey, further supporting the inferred Norian age and tentatively placing it in the mid-Norian. Correlations with the northern North Sea and the Alps are also suggested. Results from Doniford Bay, where tectonic dips are steeper but which cannot be correlated precisely with the St Audrie's section, are incorporated for the calculation of the mean direction of Characteristic Remanent Magnetization which has declination $30.8^{\circ}$ and inclination $+34.3^{\circ}\left(N=27\right.$ horizons, $\left.\alpha_{95}=5.1^{\circ}\right)$. The corresponding palaeomagnetic pole is $49.6^{\circ} \mathrm{N}, 128.4^{\circ} \mathrm{E}\left(\mathrm{dp}=3.3^{\circ}, \mathrm{dm}=5.8^{\circ}\right)$, which also correlates with the Norian of the Newark Basin, while possibly indicating that small adjustments should be made to the orientation of all or part of Britain within the 1965 Bullard et al. configuration as a representation of Late Triassic geography.
\end{abstract}

Keywords: Triassic, Norian, Somerset, magnetostratigraphy, palaeomagnetism.

Forty years after the pioneering palaeomagnetic studies of the Triassic in Britain (Clegg et al. 1954; Creer 1957), the palaeomagnetism of these rocks is again of interest for both palaeogeographic and stratigraphic reasons. For example, as uncertainties in knowledge of the past configurations of continents shrink to the scale of hundreds of kilometres, such studies can begin to contribute to the history of individual Mesozoic sedimentary basins that have subsequently been fragmented by continental break-up. Resolution of controversy over the precise form of apparent polar wander (apw) paths, as is currently an issue with respect to North America, becomes crucial in this context. For palaeoenvironmental studies, the discovery of chronometers in the geological record (e.g. facies significance of Milankovitch cyclicity), and the worldwide identification of particular geomagnetic reversals that are potentially precise correlation tools on the order of a thousand years, lends a new importance to complete determination of the Geomagnetic Polarity Time Scale back through the Mesozoic and Palaeozoic.

The palaeomagnetic database that is vital to progress on such problems in the Triassic is sparse. No pre-Callovian ocean-floor magnetic anomalies exist, and exposures of Triassic sedimentary rocks are commonly tectonized or diagenetically altered (as in the Alps) or have poor biostratigraphic control (as in the non-marine basins of western Europe and North America). Nevertheless significant progress has recently been made both in the Alpine and Mediterranean sequences (e.g. Gallet et al. 1993, 1994) and notably in the Newark Basin, New Jersey (e.g. Kent et al. 1995). The study described here is a further contribution to the database.

\section{The sequence at St Audrie's Bay and Doniford Bay, Somerset}

Late Triassic and Early Jurassic rocks, slightly flexured and somewhat disrupted by normal faulting, are well exposed over some $18 \mathrm{~km}$ between Hinckley Point and Blue Anchor on the Bristol Channel coast of Somerset. The location of this and previously published studies of late Triassic rocks from Britain is shown in Fig. 1. The present study concentrates on the upper part of the Mercia Mudstone Group (formerly 'Keuper Red Marls' and 'Tea Green Marls') in St Audrie's Bay from UK National Grid Ref. [ST 1085 4305] to [1047 4310]; latitude $51^{\circ} 11^{\prime} \mathrm{N}$, longitude $3^{\circ} 17^{\prime} \mathrm{W}$. Here the exposed sequence consists of $67 \mathrm{~m}$ of red calcareous mudstones and siltstones with interbedded greenish beds of similar lithology, overlain by c. $5 \mathrm{~m}$ of 'Tea Green Marl'. It has been logged by the Geological Survey (Whittaker \& Green 1983, fig. 9); their section is reproduced as Fig. 2, with the palaeomagnetic log from this study added. The rocks are believed to be of lacustrine origin, and biostratigraphic control is provided only by miospores which have been recovered from the upper $14 \mathrm{~m}$ of the redbed succession (above a level between palaeomagnetic sampling horizons 45 and 42; Fig. 1) and from the overlying Blue Anchor Formation (Warrington \& Whittaker 1984). The base of the Rhaetian is, on palynological evidence, at least $8 \mathrm{~m}$ below the top of that formation but cannot be placed with certainty and the lower beds are assigned to a Rhaetian or Norian age. The base of the Norian in Somerset is above the palynologically dated late Carnian North Curry Sandstone; this unit is not exposed in the Somerset coastal sections and the lowest beds exposed there are regarded as post-Carnian (i.e. Norian). The beds generally dip gently to the 


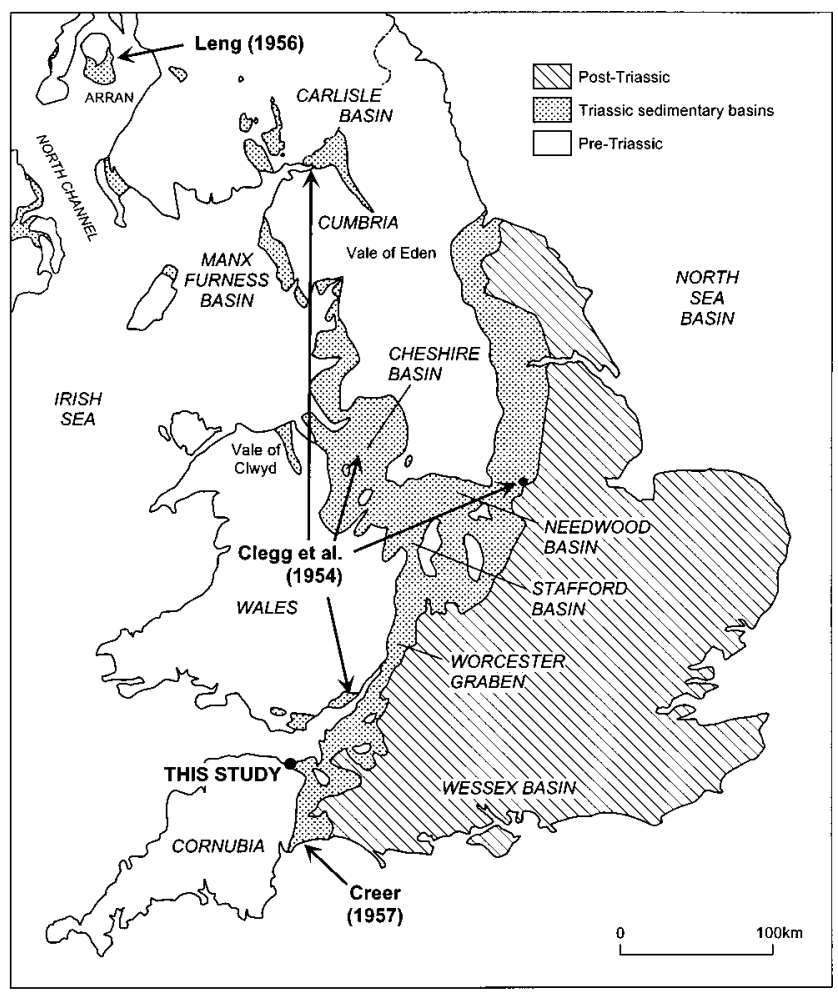

Fig. 1. Location map of the present and previous palaeomagnetic studies of late Triassic rocks in Britain, on a base map showing Triassic sedimentary basins (after Audley-Charles 1992 and Warrington et al. 1980).

southwest but small scale basins and domes occur which, as Whittaker \& Green (1983) note, are related to the near surface presence of Devonian rocks e.g. near Perry Gully. Whether these fluctuations in dip are depositional or tectonic is discussed later. Between Doniford Bay and Watchet Harbour moderate and variable northerly dips in the red marls are certainly of tectonic origin, associated with the nearby Watchet Fault.

\section{Palaeomagnetic sampling and properties}

Block hand-samples and short drilled cores (according to convenience and accessibility) were collected at 22 horizons in the eastern part of the fresh cliff section at St Audrie's Bay, and oriented by clinometer and magnetic compass. In such redbed sequences it cannot be taken for granted that the stable natural remanent magnetization (NRM) dates from the deposition of the beds, so it is important to gather whatever evidence is possible that may throw light on this. The contrasting dips in the beds at Watchet (latitude $51^{\circ} 11^{\prime} \mathrm{N}$, longitude $3^{\circ} 19^{\prime} \mathrm{W}$ ) offer the opportunity to determine whether the remanence predates tilting, so samples were collected by the same procedures at six horizons there.

The section studied continues upwards into the Lower Jurassic (Warrington \& Ivimey-Cook 1995), and contains a candidate Global Stratotype Section and Point for the base of the Jurassic (Warrington et al. 1994). There was thus a special incentive for extending the magnetostratigraphic coverage continuously into the Lower Jurassic and our sampling was continued westwards across St Audrie's Bay, above the Grey Marl (which was too friable to sample for our purposes), through the Rhaetian Penarth Group and into the Psiloceras planorbis beds of the Lower Lias [ST 1020 4330]. However no remanence of palaeomagnetic significance was detected in these higher beds and the results are not reported further.

Between three and eight cylindrical specimens, nominally $25 \mathrm{~mm}$ diameter and $23 \mathrm{~mm}$ long, were prepared from each horizon. Remanence was measured using a Cryogenic Consultants cryogenic magnetometer. Thermal demagnetization was performed in 'magnetic field-free' $(<5 \mathrm{nT})$ ovens, one manufactured by Magnetic Measurements and the other in the University of Leeds. The alternating field demagnetizer was made by O. Totland (Geological Survey of Norway); magnetic susceptibility was measured on a Kappabridge (Geofysika Brno) and isothermal remanent magnetization (IRM) was imposed using a Molspin pulse magnetizer.

Natural remanent magnetization (NRM) intensities in the redbeds of the Mercia Mudstone were in the range 1-7 mA $\mathrm{m}^{-1}$ while the grey-green horizons (including the 'Tea Green Marl') were an order of magnitude weaker $\left(\geq 0.06 \mathrm{~mA} \mathrm{~m}^{-1}\right)$. NRM directions (Fig. 3a) almost all had positive inclination, but with no discernible tendency to group around the present geomagnetic field direction. Thermal and alternating field (a.f.) demagnetization revealed that the NRM is dominated by a soft (low blocking temperature, $T_{\mathrm{b}}$, and low coercivity of remanence, $H_{\mathrm{cr}}$ ) component that in many cases is roughly aligned with the axis of our cylindrical specimens (Figs $3 \mathrm{~b}$ and 5). It thus appears that this soft component is mostly due to imposition of magnetization during the coring of our specimens, whether in the field or under a drill press in the laboratory.

Demagnetization characteristics of the Mercia Mudstones were remarkably consistent and straightforward. Soft components were removed by either a.f. or thermal demagnetization. These were mostly close to the direction of sample drilling but in some cases there was also evidence of magnetization close to the present geomagnetic field direction (Fig. 4b). Once this was removed, usually by $450^{\circ} \mathrm{C}$ or $50 \mathrm{mT}$ treatment, the characteristic remanent magnetization (ChRM) was usually isolated: either northeast and downward or southwest and upward - referred to as Normal and Reversed polarity respectively. Horizon 1 is typical of the simpler cases: during progressive demagnetization of a red sample (Fig. 4a) the remanence direction first swings away from the axis of drilling of this sample (denoted by D in the figure) suggesting removal of a soft component close to the direction of drilling by heating to $450^{\circ} \mathrm{C}$. The characteristic remanent magnetization $(\mathrm{ChRM})$ has blocking temperatures ranging from below $450^{\circ} \mathrm{C}$ up to the Curie temperature of hematite. In a grey-green sample (Fig. $4 \mathrm{~b}$ ), the soft component may be in the present geomagnetic field direction rather than the direction of drilling; it is removed by $200^{\circ} \mathrm{C}$ treatment and the ChRM has the characteristics of magnetite. Throughout this study, the ChRM in the redbeds invariably unblocked close to $670^{\circ} \mathrm{C}$, and in the grey-green horizons close to $580^{\circ} \mathrm{C}$, probably indicative of hematite and magnetite respectively. This conclusion is supported by the presence of high coercivity (>80 mT) ChRM in the redbeds but not in the grey/green rocks, and by hysteresis measurements of IRM up to 0.8 Tesla which indicated saturation of the grey-green rocks by $c .0 .5 \mathrm{~T}$, whereas the red rocks were not magnetically saturated in the maximum field available. Finally, thermal demagnetization of the IRMs revealed the same contrasting maximum blocking temperatures in red and grey-green specimens as for their NRMs. 


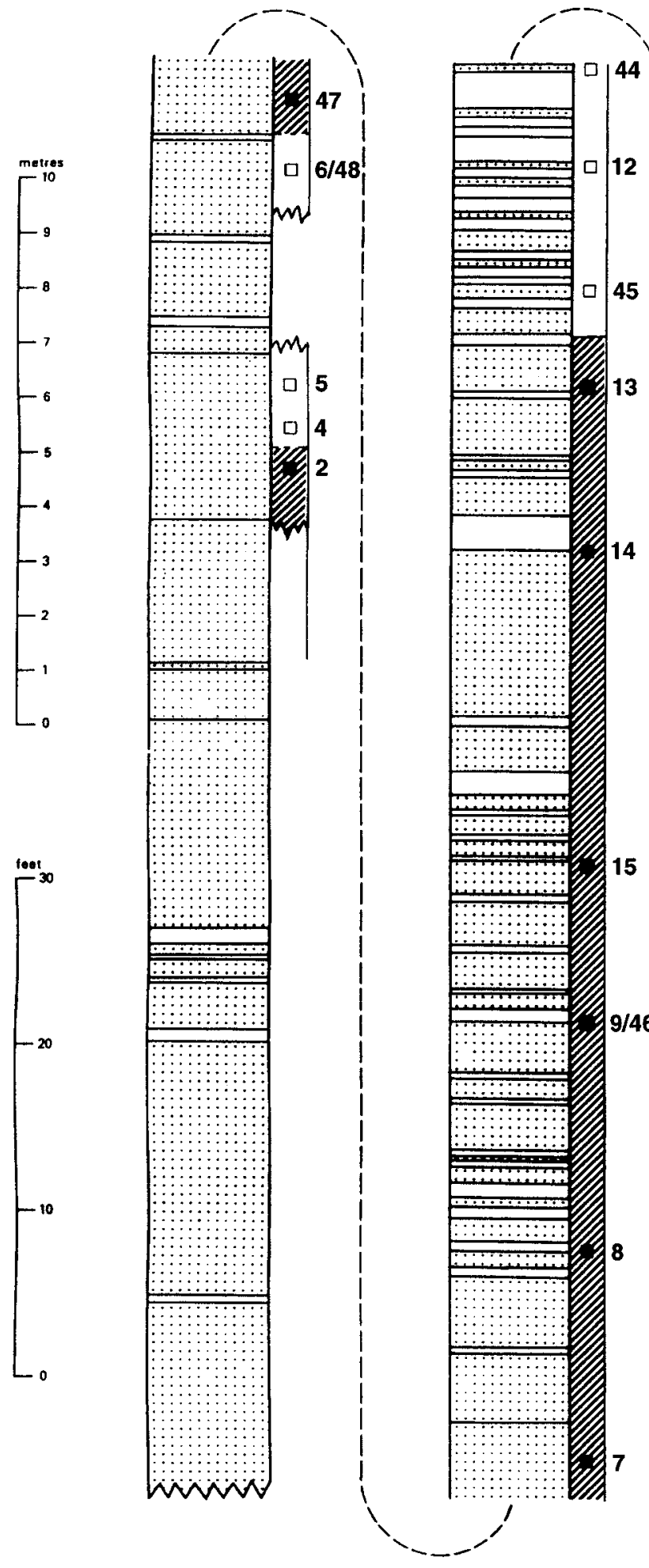

Figure 5 illustrates more complex characteristics, where the NRM has three components. The soft component is either related to drilling, or is close to the present field, or in a few cases is in other unexplained directions. The hard component, the ChRM, is either southwest and upward ('Reversed') or northeast and down ('Normal'), while the intermediate component is either antiparallel to the ChRM or close to the present field direction. In a minority of cases the superimposed
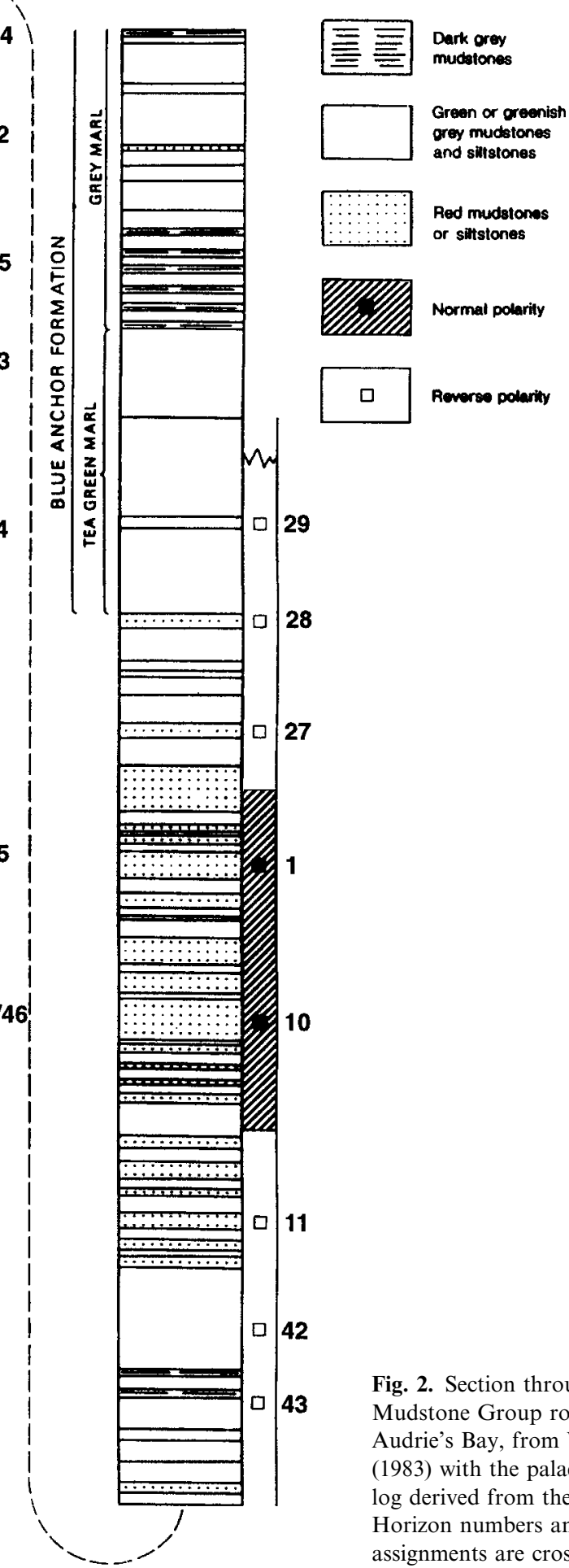

Fig. 2. Section through the Mercia Mudstone Group rocks exposed at St Audrie's Bay, from Whittaker \& Green (1983) with the palaeomagnetic polarity $\log$ derived from the present study. Horizon numbers and polarity assignments are cross-referenced to Table 1 .

component overlaps the coercivity or blocking temperature range of the ChRM completely; in those instances the varying ratio of soft and ChRM components is expressed by the planar trajectory of progressive demagnetization and the direction of this trajectory is indicative of the polarity of ChRM even where that has not been isolated. Thermal demagnetization of three-component IRMs revealed similar behaviour to that of NRM, i.e. a degree of correlation between low $H_{\mathrm{cr}}$ and low $T_{\mathrm{b}}$, 


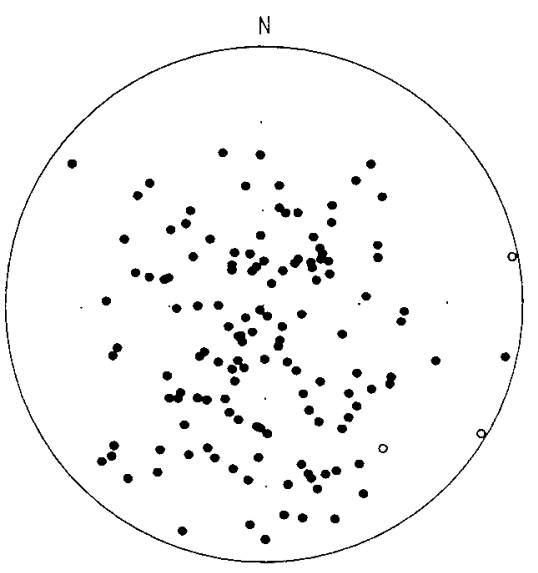

(a)

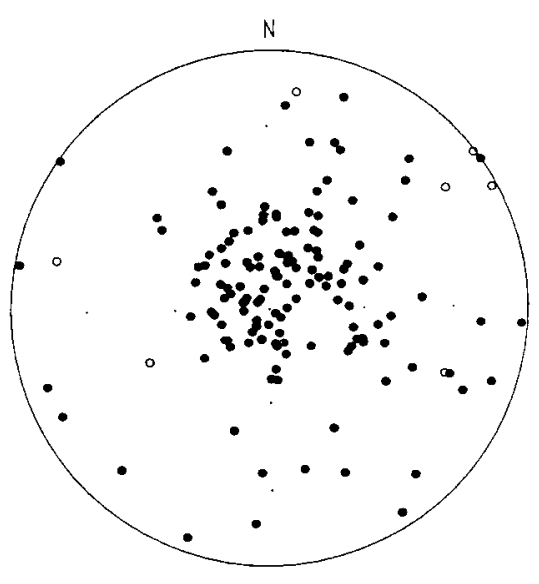

(b)
Fig. 3. (a) Total NRM directions in situ and (b) directions of the soft component of NRM (removed in the first thermal or a.f. demagnetization step, to $100^{\circ} \mathrm{C}$ or $2 \mathrm{mT}$ respectively) plotted in core-coordinates with the core axis at the centre of the projection. Solid and open symbols denote downward and upward directions respectively. Equal area projection.
Sample: 1-2A

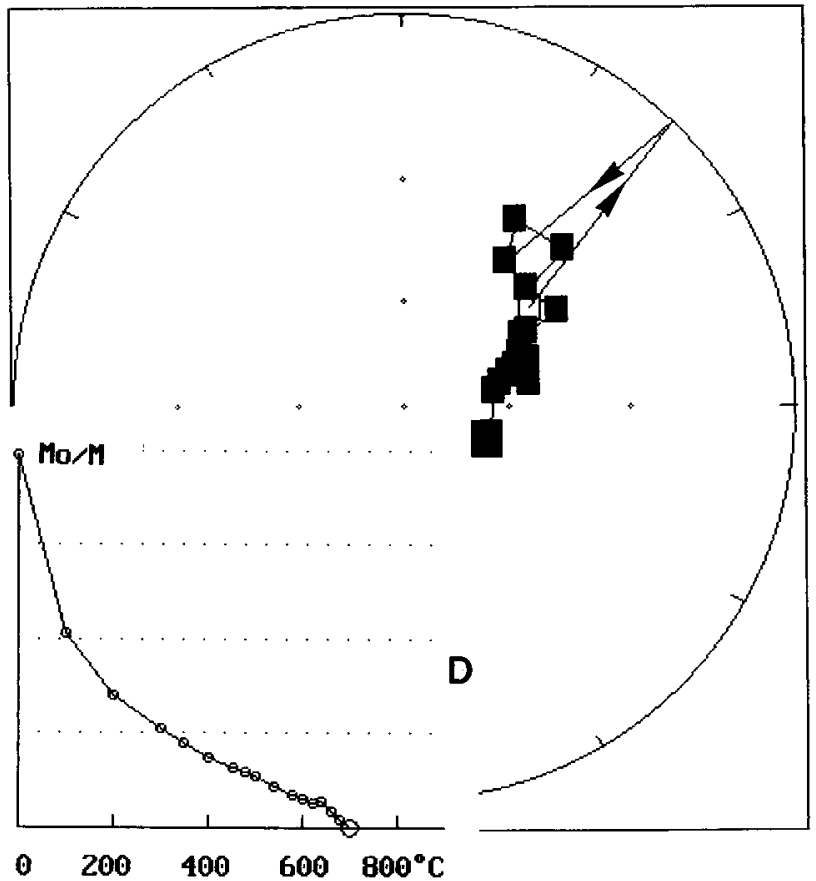

Sample: 1-3A

(a)

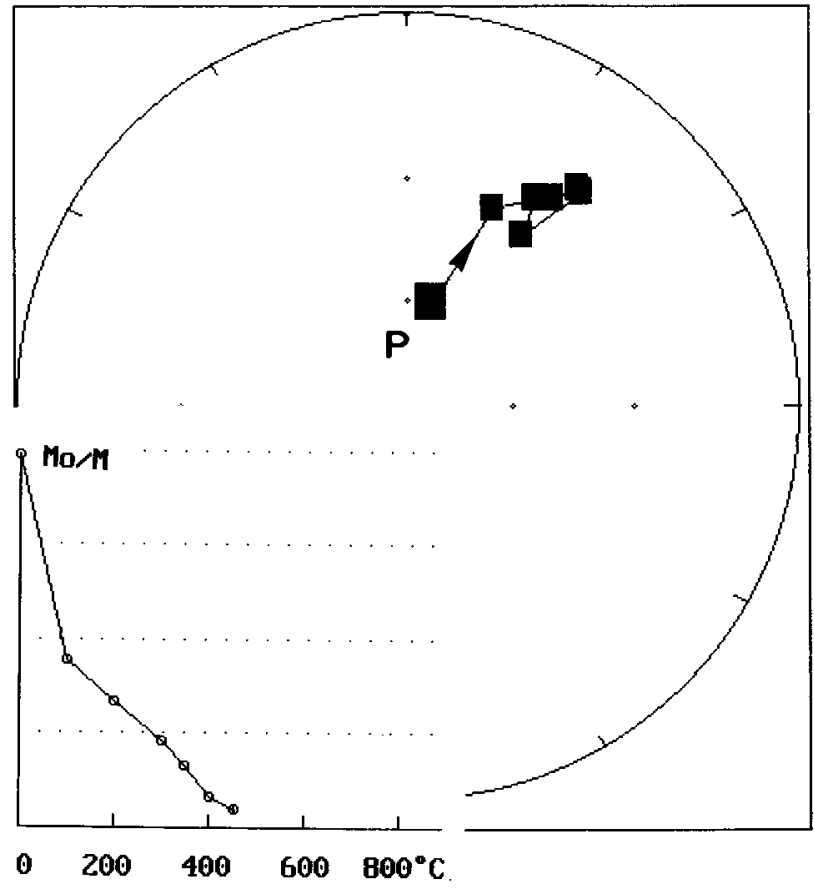

(b)

Fig. 4. Examples of simple magnetic properties: stereographic projection and decay curves of thermal demagnetization of (a) red and (b) green lithologies within $20 \mathrm{~cm}$ of each other stratigraphically at horizon 1 (Fig. 2, Table 1). Both have 'white' blocking temperature spectra but the maximum $T_{\mathrm{b}} \mathrm{s}$ are different - corresponding to hematite and magnetite respectively. In (a), 'D' denotes the direction of drilling. In (b), 'P' denotes the present Earth's magnetic field direction. All directions in this figure are downwards.

analogous to the characteristics of the soft component of NRM (Fig. 5), but no correlation between blocking temperature and coercivity in the harder fraction of IRM.

The intensity of IRM in the redbeds $\left(2-3 \mathrm{~A} \mathrm{~m}^{-1}\right)$ is consistent with a hematite content of $c .0 .1 \%$. Since the saturation remanence of magnetite is nearly 100 times that of hematite, and the magnetite-bearing mudstones had typically a tenth of the NRM intensity of the redbeds, the abundance of magnetite in the former is of the order of one-thousandth that of hematite in the red rocks, i.e. c. 1 ppm.

\section{The characteristic remanence}

Detailed Fisher (1953) statistics of the ChRM of the studied rocks are given in Table 1. Fisher precision estimates, $k$, range from 7 to 120 , but much of this variation is attributable to the small number of oriented specimens from each horizon - a consequence of designing this study more for polarity stratigraphy than for formal determination of mean ChRM. $k$ is an imprecise measure of Fisher's (1953) precision parameter $\kappa$ for $n \leq 5$. The overall impression is 

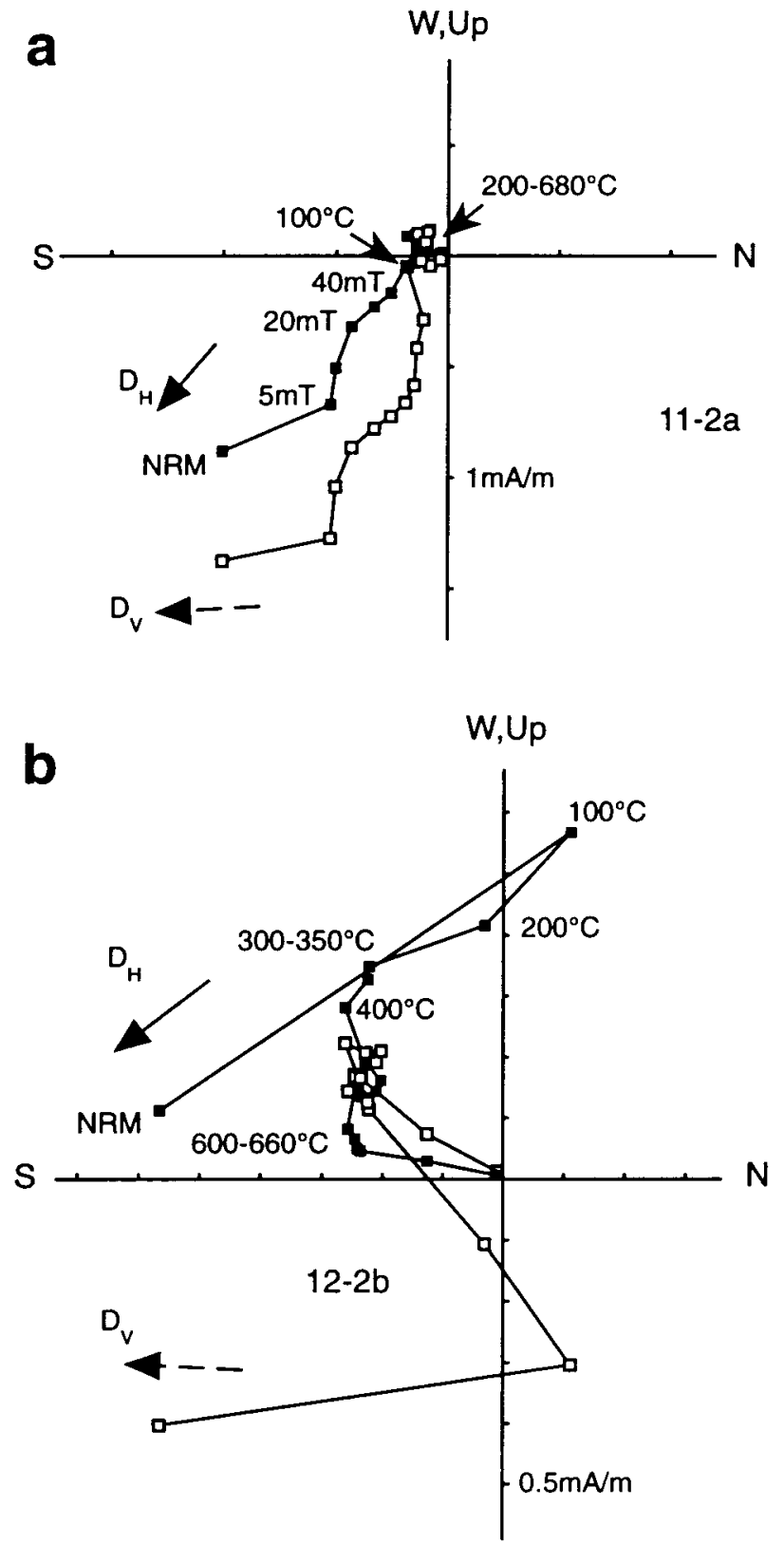

Fig. 5. Examples of more complex palaeomagnetic properties. (a) Specimen 11.2a: a drilling-imposed component is first demagnetized in alternating fields of less than $5 \mathrm{mT}$; then further af treatment up to $40 \mathrm{mT}$ removes a downward component, revealing the reverse polarity ChRM which has blocking temperatures concentrated mainly between 660 and $685^{\circ} \mathrm{C}$. (b) In $12.2 \mathrm{~B}$ the drilling-imposed component has $T_{\mathrm{b}}<100^{\circ} \mathrm{C}$; the intermediate $T_{\mathrm{b}}$ component could be Triassic with normal polarity, and the high $T_{\mathrm{b}}$ component is Triassic reversed. (a) and (b) are orthogonal projections in situ; solid and open symbols denote directions projected on to the horizontal and vertical N-S planes respectively; $D_{\mathrm{h}}, D_{\mathrm{v}}$ denote the horizontal and vertical projections of the direction of drilling.

of rather uniform characteristics of remanence throughoutincluding its dispersion. This impression is confirmed by the summary statistics for each of the sampled sections (Table 2) in which $k$ is typically $c$. 40 , as it is for within-site dispersion (Table 1).

There are two lines of evidence relevant to the age of the ChRM in these rocks. First and most decisive is that the polarity is consistent within each palaeomagnetic 'horizon'. This consistency is both lateral (over typically a few metres of cliff-section) and vertically over a few tens of centimetres. In a few cases (horizons 1, 6, 9, 10, 27) both red and greygreen samples were taken within the same horizon. The alternation of red and green lithology is evidently syn- or early diagenetic, and the within-horizon consistency in remanence polarity is also indicative of syn- or early diagenetic origin. At horizon 12 (Fig. 5b) the high blocking temperature component is reversed polarity, but the planar demagnetization trajectory appears to indicate that intermediate blocking temperature material may be magnetized antiparallel, i.e. normal polarity. We interpret this as diagenetic remanence in hematite as it grows through the superparamagnetic grainsize threshold.

Supporting evidence for the ancient origin of the ChRM derives from the finding that in the strata at the west end of Doniford Bay, where the northerly dips contrast with those at St Audrie's, the ChRMs are more concordant with the St Audrie's ChRM when corrected for tectonic tilt (Fig. 6 and Table 2). The in situ directions among the normally magnetized horizons have an elongate, non-Fisherian distribution; when tilt-corrected, a rather better grouped and Fisherian distribution emerges. The argument is not statistically compelling, because the improvement in Fisher's $k$ between the in situ and dip-corrected statistics is only marginal (19.3-31.0) when each horizon is given unit weight. When each section is given unit weight (to avoid the predominance of the 18 horizons in our main sampled section), the improvement in $k$ is more than tenfold, a statistically significant improvement at 95\% confidence on either McElhinny's (1964) of McFadden \& Jones' (1981) criteria. Again, the significance of this should not be exaggerated, because conclusions based on three 'independent' observations are subject to enormous statistical uncertainty. In any case this 'fold-test' is only of limited use in constraining the age of ChRM because the tilting is believed to be associated with the development of the Watchet Fault, the age of which is not well constrained and which may have a prolonged history of reactivation. Thus to determine that remanence is pre-tilting falls far short of establishing that it is of primary Jurassic origin.

There is a further point about the relation between remanence and structure that is worth mentioning: the mean directions of ChRM at localities 2, 4 and 5, at the east end of St Audrie's Bay, are more concordant with the rest when they are 'tilt-corrected' using the regional dip of the St Audrie's section than if their local strike and dip is applied (Fig. 6 and Table 2). As remarked earlier, the area of local variation in dip of the Triassic beds is close to where Devonian grits approach the surface at Perry Gully and variations in ChRM therefore indicate that the local structure there is due to depositional draping of the Late Triassic beds over the contemporary land surface.

The Fisher statistics of the normal and reverse polarity groups in the main St Audrie's sequence are:

Normal $N=9, \quad k=42.6, \quad a_{95}=8.0^{\circ}, \quad D=36.3^{\circ}, \quad I=+42.9^{\circ}$, $\lambda_{\mathrm{p}}=24.9^{\circ} \pm 6.4^{\circ}$

Reverse $\quad N=9, \quad k=79.4, \quad a_{95}=5.8^{\circ}, \quad D=207.9^{\circ}, \quad I=-29.7^{\circ}$, $\lambda_{\mathrm{p}}=15.9^{\circ} \pm 3.8^{\circ}$.

The deviation from antiparallel is significant at the $95 \%$ confidence level. Whether this is a real feature of the Late Triassic geomagnetic field or due to incomplete removal of the 
Table 1. Statistics of stable NRM directions at each horizon

\begin{tabular}{|c|c|c|c|c|c|c|c|c|c|c|}
\hline \multirow{2}{*}{$\begin{array}{l}\text { Horizon } \\
\text { number }\end{array}$} & \multirow{2}{*}{$\begin{array}{c}\text { Strat. height }(\mathrm{m}) \\
\text { above }(+) \text { or } \\
\text { below }(-) \text { base } \\
\text { of TGM }\end{array}$} & \multirow[b]{2}{*}{$n$} & \multirow[b]{2}{*}{$r$} & \multirow[b]{2}{*}{$k$} & \multirow[b]{2}{*}{$\alpha 95$} & \multicolumn{2}{|c|}{ in situ } & \multicolumn{2}{|c|}{ tilt corrected } & \multirow[b]{2}{*}{ Polarity } \\
\hline & & & & & & $\mathrm{D}$ & I & $\mathrm{D}$ & I & \\
\hline \multicolumn{11}{|c|}{ West end of St Audrie's Bay } \\
\hline 29 & $+1.5 \mathrm{~m}$ & $3 *$ & 2.8747 & & & 211.0 & -34.6 & 202.6 & -39.1 & $\mathrm{R}$ \\
\hline 28 & 0 & 2 & 1.9934 & & & 207.0 & -29.4 & 200.0 & -33.2 & $\mathrm{R}$ \\
\hline 27 & 2 & 5 & 4.9665 & 119.5 & 7.0 & 218.1 & -17.6 & 214.2 & -23.8 & $\mathrm{R}$ \\
\hline 1 & 4.5 & 5 & 4.8000 & 20.1 & 14.2 & 31.7 & +40.4 & 21.2 & +42.8 & $\mathrm{~N}$ \\
\hline 10 & 7 & 5 & 4.9488 & 78.2 & 8.7 & 52.6 & +45.3 & 44.3 & +52.2 & $\mathrm{~N}$ \\
\hline 11 & 11 & 4 & 3.8806 & 26.0 & 18.4 & 203.6 & -21.6 & 199.5 & -24.5 & $\mathrm{R}$ \\
\hline 42 & 13 & $0 *$ & & & & & & & & $\mathrm{R}$ \\
\hline 43 & 14 & 7 & 6.9083 & 65.4 & 7.5 & 220.5 & -30.1 & 215.1 & -35.5 & $\mathrm{R}$ \\
\hline 44 & 16 & $4 *$ & 3.6595 & 8.8 & 32.8 & 205.3 & -23.3 & 200.9 & -27.2 & $\mathrm{R}$ \\
\hline 12 & 18 & 7 & 6.7196 & 21.4 & 13.4 & 207.7 & -21.6 & 202.7 & -24.8 & $\mathrm{R}$ \\
\hline 45 & 20 & 4 & 3.8243 & 17.1 & 22.9 & 223.6 & -22.8 & 219.2 & -31.2 & $\mathrm{R}$ \\
\hline 13 & 22 & $2 *$ & 1.9835 & & & 44.6 & +48.9 & 32.0 & +58.0 & $\mathrm{~N}$ \\
\hline 14 & 26 & 5 & 4.9432 & 70.4 & 9.2 & 49.1 & +32.4 & 40.0 & +39.8 & $\mathrm{~N}$ \\
\hline 15 & 31.5 & $5^{*}$ & 4.8797 & 33.3 & 13.5 & 36.3 & +40.5 & 22.9 & +44.3 & $\mathrm{~N}$ \\
\hline $9 / 46$ & 33.5 & 5 & 4.7328 & 15.0 & 20.4 & 37.7 & +39.0 & 27.9 & +43.7 & $\mathrm{~N}$ \\
\hline 8 & 37.5 & 5 & 4.9234 & 52.2 & 10.7 & 47.6 & +17.2 & 43.5 & +24.8 & $\mathrm{~N}$ \\
\hline 7 & 41.5 & 5 & 4.8864 & 35.2 & 13.1 & 45.1 & +26.2 & 38.8 & +33.1 & $\mathrm{~N}$ \\
\hline 47 & -43 & 4 & 3.9758 & 71.8 & 11.0 & 59.6 & +32.7 & 53.3 & +42.9 & $\mathrm{~N}$ \\
\hline $6 / 48$ & -44.5 & $5 *$ & 4.8343 & 24.1 & 15.9 & 225.8 & -24.6 & 219.9 & -31.7 & $\mathrm{R}$ \\
\hline \multicolumn{11}{|c|}{ East end of St Audrie's Bay } \\
\hline 5 & -48 & 5 & 3.9036 & 41.5 & 12.0 & 212.8 & -15.1 & 212.8 & -15.1 & $\mathrm{R}$ \\
\hline 4 & -49 & 6 & 5.9262 & 62.6 & 8.5 & 221.5 & -21.8 & 223.5 & -16.4 & $\mathrm{R}$ \\
\hline 2 & -50 & 4 & 3.9715 & 105.1 & 9.0 & 47.4 & +34.6 & 45.5 & +31.8 & $\mathrm{~N}$ \\
\hline \multicolumn{11}{|c|}{ West end of Doniford Bay } \\
\hline 21 & & 4 & 3.8740 & 23.8 & 19.2 & 59.5 & +71.6 & 19.2 & +40.0 & $\mathrm{~N}$ \\
\hline 22 & & 2 & 1.9722 & & & 12.1 & +53.1 & 6.7 & +14.8 & $\mathrm{~N}$ \\
\hline 23 & & $3 *$ & 2.9609 & & & 58.2 & +78.1 & 12.4 & +44.1 & $\mathrm{~N}$ \\
\hline 24 & & $1 *$ & & & & 46.1 & +61.2 & 21.2 & +28.1 & $\mathrm{~N}$ \\
\hline 25 & & 3 & 2.9711 & 69.2 & 14.9 & 225.5 & -31.5 & 219.5 & -13.4 & $\mathrm{R}$ \\
\hline 26 & & 4 & 3.5669 & 6.9 & 37.6 & 54.2 & +54.5 & 53.8 & +30.5 & $\mathrm{~N}$ \\
\hline
\end{tabular}

$n$ is number of specimens used in the calculation and $r$ the resultant of $n$ unit vectors; $k$ is Fisher's (1953) precision estimate and $\alpha 95$ the semi-angle of the cone of $95 \%$ confidence about the mean direction with declination and inclination $D, I$.

Polarity is denoted either normal $(\mathrm{N})$ or reversed $(\mathrm{R})$ relative to the present geomagnetic field. TGM denotes Tea Green Marl.

*Great circle analysis of multicomponent NRM in further samples at this horizon confirms the polarity assignment.

Table 2. Summary statistics of characteristic remanence directions

\begin{tabular}{|c|c|c|c|c|c|c|c|c|c|c|}
\hline & \multirow[b]{2}{*}{$n$} & \multirow[b]{2}{*}{$r$} & \multirow[b]{2}{*}{$k$} & \multirow[b]{2}{*}{$\alpha 95$} & \multicolumn{2}{|c|}{ in situ } & \multicolumn{2}{|c|}{$\begin{array}{l}\text { Corrected for } \\
\text { regional dip }\end{array}$} & \multicolumn{2}{|c|}{$\begin{array}{l}\text { Corrected for } \\
\text { local dip }\end{array}$} \\
\hline & & & & & $\mathrm{D}$ & I & $\mathrm{D}$ & I & $\mathrm{D}$ & I \\
\hline West St Audrie's (main section) & $\begin{array}{l}18 \\
18\end{array}$ & $\begin{array}{l}17.5700 \\
17.5642\end{array}$ & $\begin{array}{l}39.9 \\
39.0\end{array}$ & $\begin{array}{l}5.5 \\
5.6\end{array}$ & 39.0 & +30.8 & 31.8 & +36.0 & 31.9 & +36.6 \\
\hline East St Audrie's & $\begin{array}{l}3 \\
3\end{array}$ & $\begin{array}{l}2.9566 \\
2.9614\end{array}$ & $\begin{array}{l}46.1 \\
51.8\end{array}$ & $\begin{array}{l}18.4 \\
17.3\end{array}$ & 40.2 & +23.9 & 34.8 & +29.5 & 40.4 & +21.2 \\
\hline St Audrie's, combined & $\begin{array}{l}21 \\
21\end{array}$ & $\begin{array}{l}20.5105 \\
20.4268\end{array}$ & $\begin{array}{l}41.0 \\
34.7\end{array}$ & $\begin{array}{l}5.0 \\
5.5\end{array}$ & 39.2 & +29.8 & 32.3 & +35.0 & 33.03 & +34.5 \\
\hline Doniford & $\begin{array}{l}6 \\
6\end{array}$ & $\begin{array}{l}5.7383 \\
5.6965\end{array}$ & $\begin{array}{l}19.1 \\
16.5\end{array}$ & $\begin{array}{l}15.7 \\
17.0\end{array}$ & 43.2 & +59.4 & & & 25.7 & +29.5 \\
\hline All 3 combined & $\begin{array}{l}27 \\
27 \\
27\end{array}$ & $\begin{array}{l}25.6520 \\
26.0877 \\
26.1620\end{array}$ & $\begin{array}{l}19.3 \\
28.5 \\
31.0\end{array}$ & $\begin{array}{l}6.5 \\
5.3 \\
5.1\end{array}$ & 39.8 & +36.2 & & & $\begin{array}{l}31.6 \\
30.8\end{array}$ & $\begin{array}{l}+33.4 \\
+34.3^{*}\end{array}$ \\
\hline
\end{tabular}

Notation as for Table 1 except that $n$ is the number of horizon means used in the calculations.

*The regional dip used to correct directions at the East St Audrie's section. 


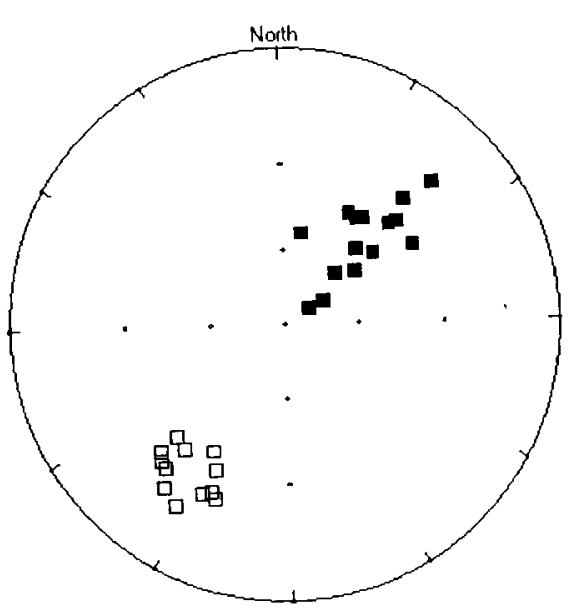

(a)

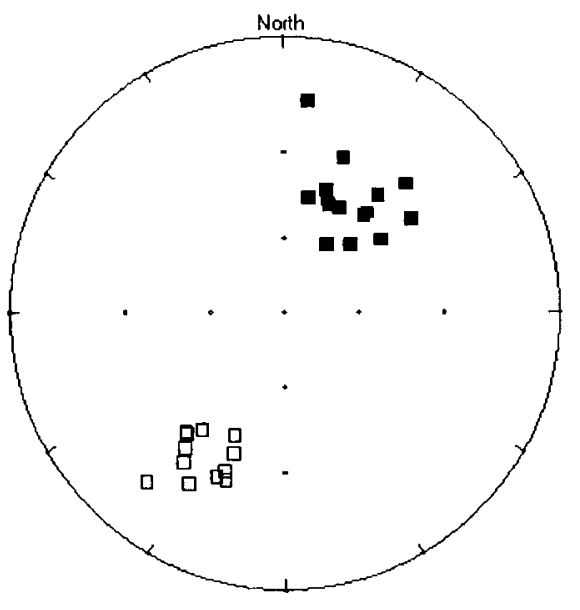

(b)

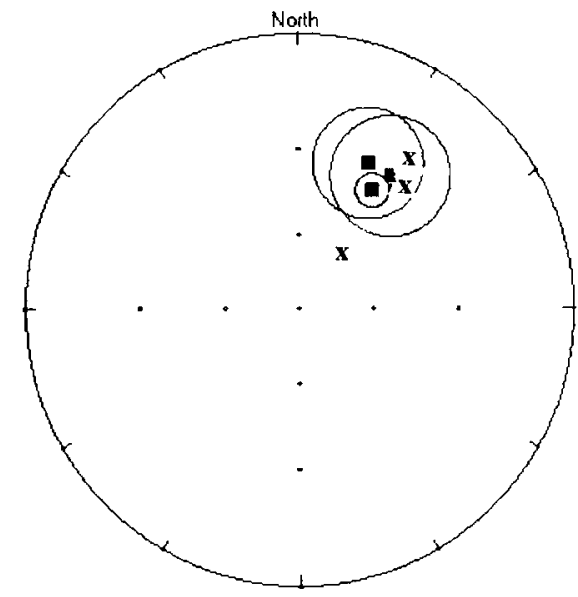

(c)

Fig. 6. Stereographic projections of horizon-mean directions (a) in situ and (b) corrected for tectonic tilting. (Results from the east end of St Audrie's Bay are corrected for regional rather than local dip, for the reason discussed in the text.) In (c) locality-means are standardized to normal polarity; in situ means are denoted by crosses (squares) are shown. Notation as in fig. 3 .

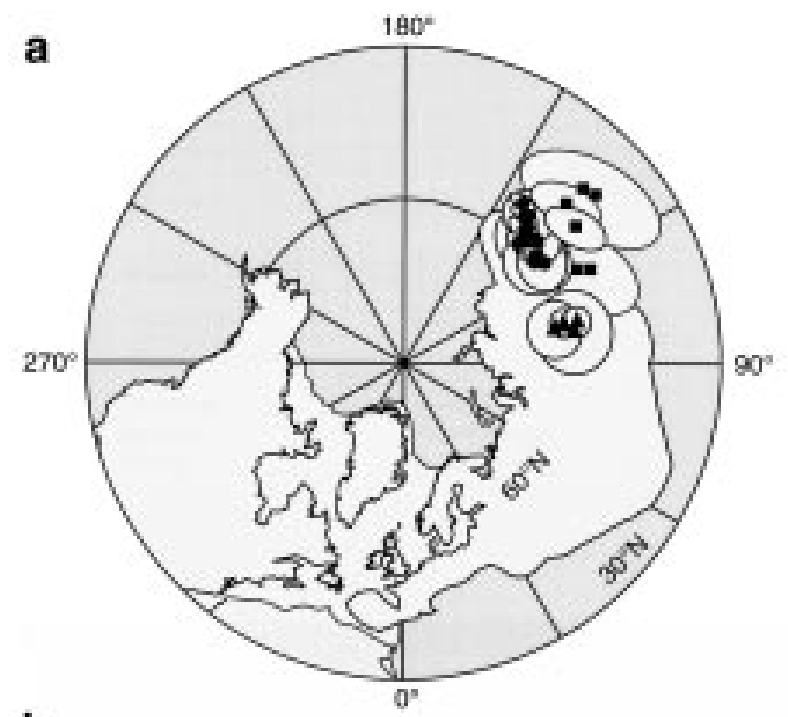

b

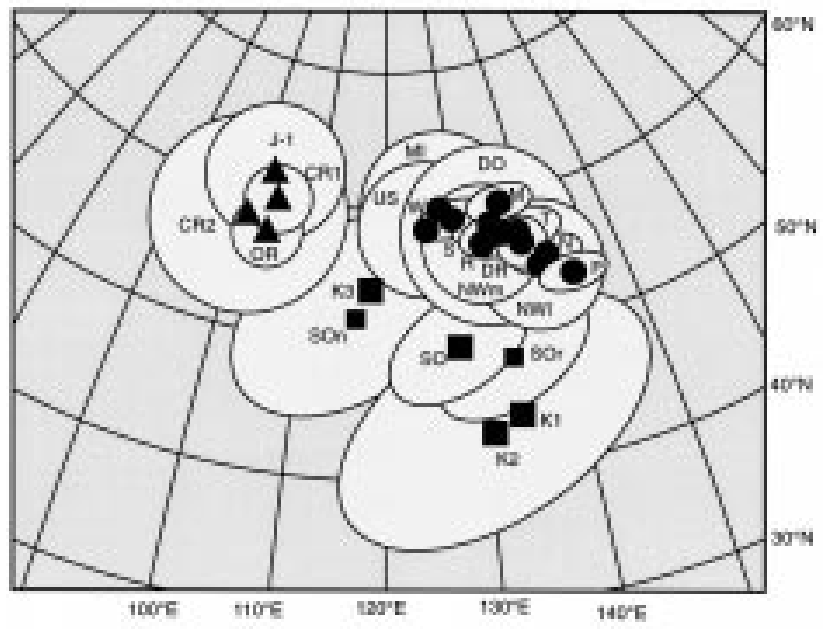

steep downward secondary component of NRM, the data are best pooled to obtain the best estimate of the mean axis of the Late Triassic palaeomagnetic field, i.e. the tilt-corrected data in Table 2 (using the regional dip at St Audrie's and the local dips at Doniford). This axis is $30.8^{\circ},+34.3^{\circ} / 210.8^{\circ},-34.3^{\circ}$ corresponding to a palaeolatitude of $18.8^{\circ} \pm 3.5^{\circ} \mathrm{N}$ and a palaeomagnetic pole position at $49.6^{\circ} \mathrm{N} 128.4^{\circ} \mathrm{E}\left(\mathrm{dp}=3.3^{\circ}\right.$, $\mathrm{dm}=5.8^{\circ}$.

\section{Tectonic rotation}

The mean palaeomagnetic pole from the present study lies approximately midway between the pole determined in the 1950s from the poorly dated sequence in Arran (Leng 1956 quoted by Irving 1964) and two poles determined from Devon by Creer (1957) and the English midlands and northwest by Clegg et al. (1954). The locations of these studies are indicated in Fig. 1 and the poles are labelled K3, K1, K2 respectively in Fig. 7. None of the 1950s studies involved progressive demagnetization of NRM; their concordance with modern results is remarkable but they should be interpreted with caution.

In Fig. 7 North American poles are rotated into European coordinates by the parameters of Bullard et al. (1965) to adjust

Fig. 7. The palaeomagnetic pole from this study (SO) is compared with Late Triassic palaeomagnetic poles from North America (rotated into a reassembly of Eurasia, Greenland and North America (Bullard et al. 1965) plotted in European coordinates). The North American data are listed by Kent \& Olsen (1997) from which this figure is adapted. The easterly group of North American poles (circles) comes from the east of the continent and also from New Mexico and west Texas; they form an apw path which youngs toward the west. The westerly located group of poles (triangles) comes from the Colorado Plateau. Poles K1 (Creer 1957), K2 (Clegg et al. 1954) and K3 (Leng 1956; Irving 1964) are based on total NRM of Triassic rocks from England and southern Scotland located in Fig. 1. SOn and SOr are the poles calculated from the normal and reversed polarity data of the present study. 


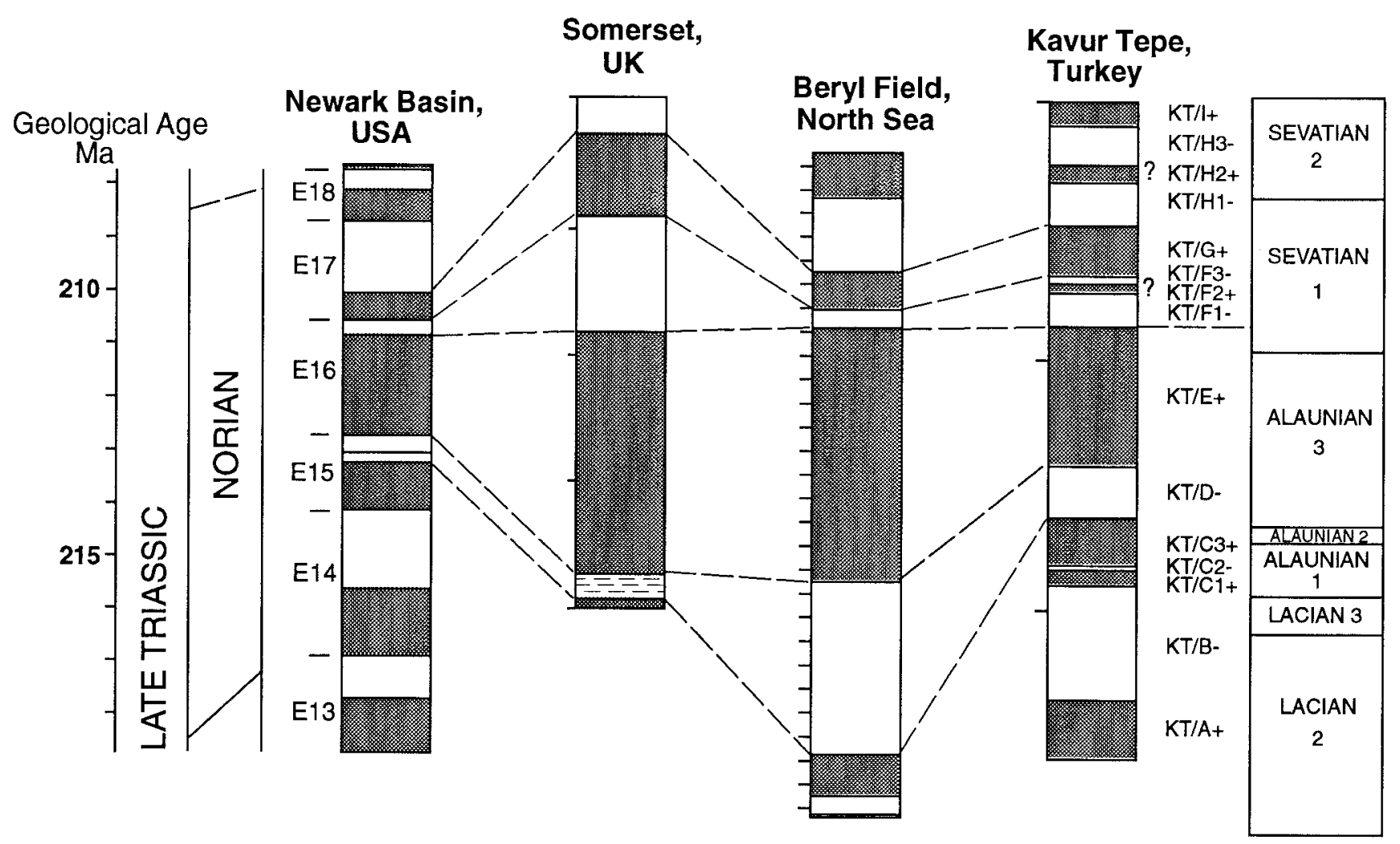

Fig. 8. A possible correlation of the polarity sequence from this study with those determined from the Newark Basin, New Jersey (Kent $e t$ al. 1995), southern North Sea (Hounslow et al. 1995) and Kavur Tepe, Turkey (Gallet et al. 1993). The Newark Section is referred to a timescale based on $202 \mathrm{Ma}$ for the 'palynological Triassic-Jurassic boundary' and the assumption of constant cyclicity in lacustrine sediments (Kent et al. 1995). The other three sections are plotted versus depth, with ticks at $10 \mathrm{~m}$ intervals. Normal polarity is plotted black, and reversed as white.

for post-Triassic opening of the North Atlantic. Three distinct groupings of poles are evident in this reassembly: the British poles, Colorado plateau poles and those from the rest of USA (principally from the Newark Basin but also further south and from New Mexico and west Texas). All the British poles are displaced $c .10^{\circ}$ clockwise from the sequence of mid- and late Triassic poles from the Newark Basin, New Jersey (Kent et al. 1995). This discrepancy would be accounted for if our sampling area in Somerset had been oriented $c .10^{\circ}$ anticlockwise in Triassic time as compared with the Bullard et al. (1965) fit shown in Fig. 7. We have no specific constraints by which to determine the boundaries or scale of the tectonic element involved in this rotation, but the fact that the old studies (mentioned above), on strata from south Devon to Arran, appear to show this same rotation suggests that much of Britain rotated as a block. The consequences of such a scale of rotation are not easily reconcilable with regional teconics. For example a tighter fit of Britain against North America such as model P of Frei \& Cox (1987) has inconsistencies in the vicinity of Newfoundland. If, instead, rotation were taken up east of Britain then it implies either compression in the North Sea or extension increasing southward in the North Sea (depending on the precise position of the tectonic pivot point). Perhaps, then, the deviation we observe is strictly local and accommodated on the Watchet Fault and other post-Triassic faults in the vicinity, and the equivocal supporting evidence from further afield in Britain is to be disregarded.

The discrepancy between the Colorado Plateau poles (Fig. 7) and the rest of North America has been the subject of fierce controversy (e.g. Kent \& Witte (1993), Molina-Garza et al. (1995)). Kent \& Olsen (1997) have pointed out that the discrepancy can be reconciled by $10-15^{\circ}$ of local rotation of the Colorado Plateau, but that rotation of the eastern seaboard (Newark to Dan River/Danville Basins) does not bring the data into concordance with Colorado. The location of the faults on which the Colorado Plateau might have rotated is not clear. We have nothing to add to this controversy except to note that local rotation of Britain can bring the British poles into concordance with the Newark poles (as discussed above) but not into concordance with the Colorado Plateau poles. To that extent our study is consistent with the conclusions of Kent \& Olsen (1997) favouring rotation of the Colorado Plateau.

\section{Magnetostratigraphy}

The section studied in the present work is believed to be of Norian age. Because its duration is unknown and it contains only three successive $\mathrm{N}-\mathrm{R}$ polarity chrons, long range correlation (Fig. 8) is inevitably uncertain. Nevertheless the matching of the long normal interval in the St Audrie's Bay section with $\mathrm{E} 16 \mathrm{~N}$ in the Newark sequence, New Jersey (Kent et al. 1995 ) is consistent with the assumption of reasonably constant sedimentation rates, and visual inspection of Fig. 8 does not suggest any other plausible correlation between St Audrie's Bay and Newark. The further correlation to the Lunde Formation in the Viking Graben in the UK northern North Sea (Hounslow et al. 1995) and to the Kavur Tepe section in southwest Turkey (Gallet et al. 1993) is made in Fig. 8 on the 
same assumption of fairly constant sedimentation rates. It should be noted that the correlation between Turkey and the North Sea differs from that made by Hounslow et al. (1995) who matched the long normal section in their core to magnetozone $\mathrm{KT} / \mathrm{C} 3+$ and hence placed their whole core one chron older than suggested here.

The pole from the Somerset study, when rotated as described in the previous section, falls at a slightly older point on the Newark Basin apparent polar wander (apw) path than correlation with E15-17 leads us to expect. However the discrepancy is only $c .3^{\circ}$ which is well within the $95 \%$ confidence limits of the various pole estimates; and if real it could be accounted for by a modest inclination error in the remanence due to compaction of the sediments. It is tempting to suggest that the sequence of poles from Britain $\mathrm{K} 1 / \mathrm{K} 2 \rightarrow \mathrm{SO} \rightarrow \mathrm{K} 3$ (denoted by squares in Fig. 7) form an apw path parallel to the Newark path and to estimate the ages of the poles K1-3 by apw path matching. However the differences between these poles are largely due to differences in inclination of NRM, and thus more likely to be due to inclination error than age difference. As mentioned earlier, this is the likely explanation for the difference between the poles calculated for the Normal and Reversed ChRM in the present study, which we know is not due to age difference because the two polarities are interdigitated.

As is well known, correlation in continental sediments is fraught with difficulties due to variable sedimentation rates and non-sequences. These same factors limit the confidence that should be placed in magnetostratigraphic correlation even when, as in all the sections correlated here, there is little doubt of the primary age of the characteristic magnetization. The correlation in Fig. 8 implies an average sedimentation rate of c. $1.5 \mathrm{~cm} \mathrm{ka}^{-1}$ in the St Audrie's Bay section. Whatever the precise depositional environment, it seems likely that this average is the consequence of alternating deposition and hiatus on scales ranging from seasonal to, perhaps, thousands of years. There is no evidence for more major hiatus that might imply that we have underestimated the timespan of the studied section. Conversely, given the detailed polarity sequence from the Newark Basin (Kent et al. 1995) it does not seem likely that our sequence with its five reversals represents less than a few million years.

\section{Conclusions}

This study provides the first palaeomagnetic pole for the Late Triassic of stable Europe to be supported by modern demagnetization measurements. The pole is nevertheless similar to those determined in Britain in the 1950s by Creer (1957), Clegg et al. (1954) and Leng (1956) - an indication of the careful experimentation of those authors. Correlation with eastern North America provides a tentative placement of the St Audrie's Bay section on the Geomagnetic Polarity Time Scale determined in the Newark Basin (Kent et al. 1995), and an attempt is made to correlate also with the UK North Sea and the Alps on the basis of published work. The correlation confirms the Norian age of the St Audrie's Bay sequence that is favoured on palynological grounds. Comparison of the palaeomagnetic pole from St Audrie's Bay with North American data leaves open the possibility of minor $\left(<10^{\circ}\right)$ reorientation of all or part of Britain within the Bullard et al. (1965) reconstruction. The discrepancy with data from the Colorado Plateau is much greater, lending support to the published contention that data from the Plateau have been subject to local tectonic reorientation.

The authors acknowledge the help and permission for access and sampling on this sensitive stretch of coast from Col. Sir Walter Luttrell and Katherine Wyndham. G. Warrington of the British Geological Survey provided much guidance on the stratigraphy and on a draft of this paper, and advice from A. Whittaker, also of BGS, was also most valuable. D. Kent kindly provided a preprint of his paper on the Dan River-Danville basin on which Fig. 7 is based. Computational and drafting assistance by C. MacNiociall, C. Grainger and A. Allen is gratefully acknowledged.

\section{References}

Audley-Charles, M.G. 1992. Triassic. In: Duff, P.McL.D. \& Smith, A.J. (eds) Geology of England and Wales. The Geological Society, London, 307-324.

Bullard, E.C., Everett, J.E. \& Smith, A.G. 1965. The fit of the continents around the Atlantic. Philosophical Transactions of the Royal Society of London, A258, 41-51.

Clegg, J.A., Almond, M. \& StubBs, P.H.S. 1954. The remanent magnetism of some sedimentary rocks in Britain. Philosophical Magazine, 45, 583-598.

Creer, K.M. 1957. The remanent magnetization of unstable Keuper Marls. Philosophical Transactions of the Royal Society of London, A250, 130-143.

Fisher, R.A. 1953. Dispersion on a sphere. Proceedings of the Royal Society of London, A217, 295-305.

FreI, L.S. \& Cox, A.V. 1987. Relative displacement between Eurasia and North America prior to the formation of oceanic crust in the North Atlantic. Tectonophysics, 142, 111-136.

Gallet, Y., Besse, J., Krysten, L., Theveniaut, H. \& Marcoux, J. 1993. Magnetostratigraphy of the Kavur type section (southwest Turkey): A magnetic polarity time scale for the Norian. Earth and Planetary Science Letters, 117, 443-456.

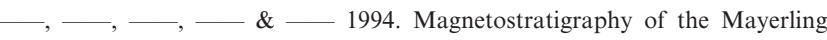
section (Austria) and Erenkolu Mezarlik (Turkey) section; Improvement of the Carnian (late Triassic) magnetic polarity time scale. Earth and Planetary Science Letters, 125, 173-191.

Hounslow, M.W., Maher, B.A., Thistlewood, L. \& Dean, K. 1995. Magnetostratigraphic correlations in two cores from the late Triassic Lunde Formation, Beryl Field, northern North Sea, UK. In: TuRnER, P. \& Turner, A. (eds.) Palaeomagnetic applications in Hydrocarbon Exploration and Production, Geological Society, London, Special Publications. 98, $163-172$.

IRVING, E. 1964. Paleomagnetism and its application to geological and geophysical problems. John Wiley and Sons, New York.

Kent, D.V. \& OlsEn, P.E. 1997. Paleomagnetism of Upper Triassic continental sedimentary rocks from the Dan River/Danville rift Basin (eastern North America). Geological Society of America Bulletin, 109, 366-377.

— \& Witte, W.K. 1993. Slow apparent polar wander for North America in the Late Triassic and large Colorado Plateau rotation. Tectonics, 12, 291-300.

— Olsen, P.E. \& Witte, W.K. 1995. Late Triassic- earliest Jurassic geomagnetic polarity sequence and paleolatitudes from drillcores in the Newark rift basin, eastern North America. Journal of Geophysical Research, 100, 14 965-14998.

LENG, J.H. 1956. The magnetic properties of minerals found in certain igneous and sedimentary rocks. Ph.D thesis, University of London.

MCElhinny, M.W. 1964. Statistical significance of the fold test in palaeomagnetism. Geophysical Journal of the Royal Astronomical Society, 8, 338-340.

McFadden, P.L. \& Jones, D.L. 1981. The fold test in palaeomagnetism. Geophysical Journal of the Royal Astronomical Society, 67, 53-58.

Molina-Garza, R.S., Geissman, J.W. \& VAN Der Voo, R. 1995. Paleomagnetism of the Dockum Group (Upper Triassic), northwest Texas: further evidence for the $\mathrm{J} 1$ cusp in the North America apparent polar wander path and implications for the rate of Triassic apparent polar wander and Colorado Plateau rotation. Tectonics, 14, 979-993.

Warrington, G. \& Ivimey-CoOK, H.C. 1995. The late Triassic and early Jurassic of coastal sections in west Somerset and South and Mid-Glamorgan. In: TAYLOR, P.D. (ed.) Field Geology of the British Jurassic. Geological Society, London, 9-30. 
\& Whittaker, A. 1984. The Blue Anchor Formation (late Triassic) in Somerset. Proceedings of the Ussher Society, 6, 100-107.

, Audley-Charles, M.G., Elliott, R.E., Evans, W.B., Ivimey-Cook, H.C., Kent, P.E., Robinson, P.L., Shotton, F.W. \& Taylor, F.M. 1980. A correlation of Triassic rocks in the British Isles. Geological Society, London, Special Reports, 13.
—, Cope, J.C.W. \& Ivimey-Cook, H.C. 1994. St Audrie's Bay, Somerset: a candidate Global Stratotype Section and Point for the base of the Jurassic System. Geological Magazine, 131, 191-200.

Whittaker, A. \& Green, G. W. 1983. Geology of the country around Westonsuper-Mare. Memoirs of the Geological Survey of Great Britain, Sheet 279 with parts of 263 and 295 .

Received 26 November 1997; revised typescript accepted 24 September 1998.

Scientific editing by David Snyder and Richard England. 